\title{
Hemşirelik Öğrencilerinin Hemşirelik Mesleği Algılarının İncelenmesi
}

\author{
Dr. Öğr. Üyesi Ş. Dilek Güven ${ }^{1}$ \\ Prof. Dr. Ayla Ünsal ${ }^{2}$
}

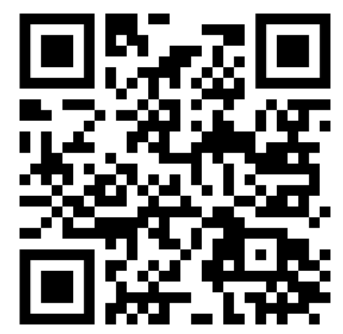

Geliş tarihi: 22.06.2020

Kabul tarihi: 02.09.2020

\section{Atıf bilgisi:}

IBAD Sosyal Bilimler Dergisi

Sayı: Özel Sayı Sayfa: 52-61

Yıl: 2020

This article was checked by Turnitin. Similarity Index 28\%

Bu makalede araştırma ve yayın etiğine uyulmuştur.

${ }^{1}$ Nevşehir Hacı Bektaş Veli Üniversitesi, Türkiye, sdguven@,nevsehir.edu.tr ORCID ID 0000-0002-2761-4665

${ }^{2}$ Kırşehir Ahi Evran Üniversitesi, Türkiye, ay unsal@hotmail.com

ORCID ID 0000-0003-3319-1600

* Sorumlu yazar
ÖZ

$\mathrm{Bu}$ araştırmanın amacı, hemşirelik öğrencilerinin hemşirelik mesleği algılarının incelenmesidir. Araştırma, iki üniversitenin sağlık yüksekokulundaki birinci ve dördüncü sınıf 334 hemşirelik öğrencisi arasından 322 gönüllü öğrenci ile tamamlanan tanımlayıcı bir çalışmadır. Veri toplamada soru formu ve Hemşirelik Mesleğini Algılama Ölçeği (HMAÖ) kullanılmıştır. . HMAÖ'nin, mesleki nitelikler ve mesleki statü olmak üzere iki alt boyutu vardır. İstatistik analiz olarak yüzde, ortalama, cronbach's alpha, bağımsız gruplarda t testi, one-way ANOVA ve LSD post hoct test yapılmıştır. Bu çalışmada, ölçeğin Cronbach alfa katsayısı 0.94, alt boyutlarından "mesleki niteliklerin" 0.95 , "mesleki statünün" 0.79 olarak bulunmuştur. Öğrencilerin yaş ortalaması $20.29 \pm 1.98$ ve \%69.9'u kızdır. Öğrencilerin \%66,1'i üniversite sınavında hemșireliği birinci sırada tercih ettiğini, $\% 6.2$ 'si hemşireliği sevmediğini, \%36.6's1 mezun olunca hastanede yönetici hemşire olarak çalışmak istediğini ve \%53.7'si kendini mesleğe hazır hissettiğini belirtmiştir. Öğrencilerin \%42.9'unun okula gelmeden önce meslek hakkında olumlu düşündüğü saptanmıştır. Öğrencilerin HMAÖ toplam ölçek puan ortalamaları $84.04 \pm 19.10$ 'dur. Bu ortalama öğrencilerin mesleki algı düzeylerinin oldukça iyi olduğunu göstermektedir. Mesleki nitelikler alt boyutu ile cinsiyet $(p<0.001)$, sınıf $(p<0.05)$, ögrencilerin hemşireliğe ilişkin duyguları $(p<0.05)$ arasında anlamlılık bulunmuştur. Mesleki statü alt boyutu ile öğrencilerin uzun süredir yaşadıkları yer $(p<0.05)$, hemşireliği isteyerek seçme $(p<0.05)$, hemşireliğe ilişkin duyguları $(\mathrm{p}<0.001)$, okula gelmeden önce hemşireliğe ilişkin düşünceleri $(p<0.001)$, bölüme başladıktan sonra hemşireliğe ilişkin düşünceleri $(p<0.001)$ arasında anlamlılık saptanmıştır. HMAÖ toplam ölçek puan ortalamaları ile cinsiyet $(\mathrm{p}<0.001)$, hemşirelik hakkındaki duyguları $(\mathrm{p}<0.01)$ arasında istatistiksel olarak anlamlılık bulunmuştur. LSD post hoc testi sonucunda hemşireliği seven, kız ve dördüncü sınıf öğrencilerin hemşirelik algılarının hemşireliği sevmeyenlere, erkek ve birinci sınıf öğrencilerine göre daha yüksek olduğu saptanmıştır. Sonuç olarak, hemşirelik öğrencilerinin hemşirelik algılarının yüksek düzeyde olduğu bulunmuştur. Hemşirelik algısı ile bazı sosyo-demografik özellikleri ve öğrencilerin hemşirelik hakkındaki düşünceleri arasında anlamlılık saptanmıştır.

Anahtar Kelimeler: Hemşirelik, Öğrenci, Meslek, Alg1 


\title{
Determining Nursing Profession Perceptions of Nursing Students
}

\author{
Assist. Prof. Dr. Ş. Dilek Güven ${ }^{1 *}$ \\ Prof. Dr. Ayla Ünsal ${ }^{2}$
}

First received: 22.06 .2020

Accepted: 02.09.2020

\section{Citation:}

IBAD Journal of Social Sciences

Issue: Special Issue Pages: 52-61

Year: 2020

\begin{abstract}
The aim of this study is to investigate that nursing profession perceptions of nursing students. The research is a descriptive study completed with 322 volunteer students among 334 first and fourth year nursing students in health colleges of two universities. The questionnaire form and the Perception of Nursing Profession Scale (PNPS). were used to collect data. PNPS has two sub-dimensions, professional qualifications and professional status. Statistical analyses were performed using the percentage, mean, cronbach's alpha, independent sample $t$ test, one-way ANOVA, and LSD post hoc test. Cronbach's alpha of professional qualities subscale was 0.95 , professional statute subscale was 0.79, and total PNPS was 0.94. The mean age of the students was $20.29 \pm 1.98$ years (Range: 17-34) and 69.9\% of them were females. It was also found that $66.1 \%$ of the nursing students preferred nursing department among their first preferences. When the distribution of students' view and thought about nursing is considered, it detected that $6.2 \%$ of them did not like nursing and $36.6 \%$ of them wanted to work in manager position after graduation. Besides it has been determined that their opinions had turned to positive after came to this school the opinions $42.9 \%$ of students nursing. It was found that PNPS total score mean for students nursing was $84.04 \pm 19.10$. A statistically significant difference were found

between professional qualities subscale and gender $(p<0.001)$, classes $(p<0.05)$, feelings of students about nursing $(\mathrm{p}<0.05)$. There was a significant difference between professional statute subscale and such as village, country, metropolitan where most of the students live longer $(\mathrm{p}<0.05)$, voluntary to take up nursing as a

career of students $(p<0.05)$, feelings of students about nursing $(p<0.001)$, opinions of students about nursing before coming to school $(\mathrm{p}<0.001)$ and after arriving at school $(\mathrm{p}<0.001)$. There was statistically significant difference between PNPS mean points and gender $(\mathrm{p}<0.001)$, feelings of students about nursing $(\mathrm{p}<0.01)$. As a result of the LSD post hoc test, it was found that the students between loving nursing, female, and fourth grade students were higher perception of nursing than the nursing students who do not like, male, and first grade students. As a result, it was found that nursing students perceived nursing profession in high level. It was found that there were significant differences between perceptions of nursing and various socialdemographics.
\end{abstract}

This article was checked by Turnitin. Similarity Index $28 \%$

1 Nevşehir Hacı Bektaş Veli University, Turkey, sdguven@nevsehir.edu.tr ORCID ID 0000-0002-2761-4665

2 Kırşehir Ahi Evran University, Turkey, ay unsal@hotmail.com

ORCID ID 0000-0003-3319-1600

Key Words: Nursing, Student, Profession, Perception 


\section{GíRIŞ}

Alg1, bireylerin duyumlar yoluyla oluşturduğu fiziksel uyaranların yanında bireyle ve bireyi çevreleyen etmenlerle ilişkili bir tanımlama sürecidir. Algılama sürecindeki en önemli etmen bireydir. Dolayısıyla bireyler, aynı kavrama ilişkin farklı algısal nitelikler ortaya koyabilirler (Kotler, 2001). Hemşireliği algılama ise, bireylerin kendilerini, çevrelerini, hemşirelik hakkında hissettiklerini ve düşündüklerini tanımlar (Eşer, Khorshid ve Denat, 2006). Bu bağlamda hemşirelik öğrencileri için mesleği algılama, öğrencilerin kendileri, çevreleri, hemşirelik ve hemşirelikteki eylemlerin uygunluğu hakkında hissettiklerini, düşüncelerini ve hemşirelik eğitimini nasıl gördüklerini tanımlar (Yücel vd., 2011).

Tüm meslekler gibi hemşirelik de, hizmet verdiği toplumdan önemli ölçüde etkilenir ve aynı zamanda da toplumu etkiler. Sosyal yapı, hemşirenin tutumlarını, hemşirelik uygulamasını ve toplumun hemşireliğe karşı tutumlarını biçimlendirir. Sosyal yapı hemşireliği meslek olarak seçenleri de etkiler (Karaöz, 2002). Hemşirelik öğrencileri için hemşirelik algısı, okula başlamadan önce hissedilir (Yücel vd., 2011; Cerit ve Çoşkun, 2018 ). Hemşirelik eğitimine yeni başlayan öğrenciler, bir anlamda toplumun hemşireliğe bakış açısını okula yansıtırlar ve hemşirelik hakkında sınırlı bir anlayışa sahip olabilirler. Hemşirelik eğitimini tercih eden bireyler içinde yaşadığı toplumun hemşireliğe bakış açısıyla hemşirelik okuluna gelmektedirler (Karaöz, 2002).

Hemşirelik mesleği algısı, öğrencinin hemşirelik eğitiminden önemli derecede etkilenir. Çalışma hayatı boyunca da gelişmeye ve olgunlaşmaya devam eder. Öğrencinin sahip olduğu olumlu mesleki algı, sağlık bakım profesyoneli olarak meslek yaşantısındaki motivasyonunu, özgüvenini, doyumunu ve sunmuş olduğu sağlık bakım hizmetinin standardını arttıracağı, kurduğu ilişkileri olumlu etkileyeceği ve mesleki gelişimine katkı sağlayacağı düşünülmektedir. Mesleki nitelikler ve mesleki statüden oluşan meslek algısının temeli okul yaşamı sırasında atılmakta, tüm meslek yaşamı boyunca devam etmekte ve mesleki felsefenin oluşmasını sağlamaktadır (Yücel vd., 2011; Cerit ve Çoşkun, 2018 ).

Literatürde hemşirelik öğrencilerinin hemşirelik algılarını belirlemek amacıyla yapılan çalışmalar vardır (Karaöz, 2002; Bezci ve Bayık, 2005; Turgay vd., 2005; Eşer, Khorshid ve Denat, 2006; Grainger ve Bolan, 2006; Eşer, Khorshid ve Denat, 2008; Zhang ve Petrini, 2008; Yücel vd., 2011; Y1lmaz ve Karadağ, 2011; Hendel ve Kagan, 2011; Patidar vd., 2011; Al Jarrah 2013; Denat, Gürol ve Şahbaz, 2016; Cerit ve Çoşkun, 2018; Şimşek ve Alpar, 2019). Bu çalışma da ise, diğerlerinden farklı olarak; hemşirelik ile henüz tanışan birinci sınıflar ile hemşirelik nosyonu kazanmada yol alan dördüncü sınıfların karşılaştırılması yapılmasıdır. Bu çalışmanın amacı, hemşirelik öğrencilerinin hemşirelik mesleği algılarının incelenmesidir.

\section{YÖNTEM}

Çalışmada herhangi bir örneklem seçme yöntemine gidilmeyerek evrenin tamamına $(\mathrm{N}=334)$ ulaşılmaya çalışılmıştır. İki üniversitenin sağlık yüksekokulundaki 2013-2014 eğitim yılında kayıtlı birinci ve dördüncü sınıf toplam 334 hemşirelik öğrencisinden gönüllü 322 öğrenci veri toplama formlarını doldurmuştur ve katılım oranı \%96.4'dür. Veri toplama formları olarak araştırmacılar tarafından literatür doğrultusunda oluşturulan soru formu ve Hemşirelik Mesleğini Algılama Ölçeği (HMAÖ) kullanılmıştır (Eşer, Khorshid ve Denat, 2006; Yücel vd., 2011; Al Jarrah, 2013; Denat, Gürol ve Şahbaz, 2016; Cerit ve Çoşkun, 2018). Eşer, Khorshid ve Denat (2006) tarafından geliştirilen HMAÖ, 5'li likert tipte ve 22 maddeden oluşmaktadır. Ölçeğin mesleki nitelikler (17 madde) ve mesleki statü ( 5 madde) olmak üzere iki alt boyutu bulunmaktadır. Ölçek maddelerinin puanlamasında 1 "kesinlikle katılmıyorum" 5 "tamamen katılıyorum" şeklinde değerlendirilmektedir. Ölçekten alınabilecek toplam puan, 22-110 arasında değişmektedir. Ölçekten elde edilen toplam puanın yükselmesi meslek algısının olumlu yönde olduğunu göstermektedir. Ölçeğin Cronbach Alpha kat sayısı 0.83 ve alt ölçeklerin Cronbach Alpha kat sayıları ise "Mesleki Nitelikler" için 0.85, "Mesleki Statü" için 0.79 bulunmuştur. (Eşer, Khorshid ve Denat, 2006). Bu çalışmada, ölçeğin Cronbach alfa katsayıs1 0.94, alt boyutlarından "mesleki niteliklerin" 0.95, "mesleki statünün" 0.79 olarak bulunmuştur. Araştırmada veriler araştırmacılar tarafından toplanmıştır. Araştırmacılar tarafından araştırmanın amacı açıklandıktan ve katılımcılardan onam alındıktan sonra veri toplama formları 
katılımcılara dağıtılmış ve doldurmaları istenmiştir. Katılımcıların veri toplama formlarını doldurmaları yaklaşık 8-10 dakika sürmüştür. Araştırmaya başlamadan önce gerekli kurum izni alınmıştır. İstatistik analiz olarak yüzde, ortalama, cronbach's alpha, bağımsız gruplarda t testi, oneway ANOVA ve LSD post hoct test yapılmıştır.

\section{BULGULAR}

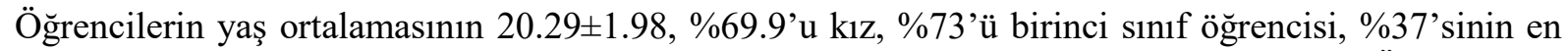
uzun yaşadığı yer şehir, \%66.8'inin annesi, \%47.8'inin de babası ilköğretim mezunudur. Öğrencilerin \%62.4'ü bölümünü isteyerek seçtiğini, \%66,1'i üniversite sınavında hemşireliği birinci sırada, \%89.4'i ilk beşinci sırada tercih ettiğini belirtmiştir. Öğrencilerin \%66.5'i hemşireliği sevdiğini, \%36.6's1 mezun olunca hastanede yönetici hemşire olarak çalışmak istediğini ve \%53.7'si kendini mesleğe hazır hissettiğini ifade etmiştir. Öğrencilerin \%42.9'u okula gelmeden önce meslek hakkında olumlu düşünürken \%57.1'i bölüme başladıktan sonra meslek hakkında olumlu düşünmeye başlamıştır (Tablo 1 ve 2).

Tablo 1. Öğrencilerin tanıtıcı özellikleri ile hemşirelik meslĕgini algılama ölçeği puanların karşıllaştırılması

\begin{tabular}{|c|c|c|c|c|c|c|c|}
\hline $\begin{array}{c}\text { Tanitıcı } \\
\text { Özellikler }\end{array}$ & n $(\%)$ & $\begin{array}{c}\text { Mesleki } \\
\text { Nitelikler } \\
\text { X } \pm \text { SD }\end{array}$ & $\begin{array}{c}\text { ANOVA } \\
\mathbf{t} \\
\mathbf{p}\end{array}$ & $\begin{array}{c}\text { Mesleki } \\
\text { Statü } \\
\text { X } \pm \text { SD }\end{array}$ & $\begin{array}{c}\text { ANOVA } \\
\mathbf{t} \\
\mathbf{p}\end{array}$ & $\begin{array}{c}\text { Ölçek Toplam } \\
\text { Puan } \\
\text { X } \pm \text { SD }\end{array}$ & $\begin{array}{c}\text { ANOVA } \\
\mathbf{t} \\
\mathbf{p}\end{array}$ \\
\hline $\begin{array}{l}\text { Yaş } \\
17-18 \text { yaş } \\
19-21 \text { yaş } \\
22-24 \text { yaş } \\
25 \text { yaş ve üzeri }\end{array}$ & $\begin{array}{c}49(15.2) \\
187(58.1) \\
79(24.5) \\
7(2.2) \\
\end{array}$ & $\begin{array}{l}67.34 \pm 15.54 \\
66.49 \pm 16.77 \\
69.82 \pm 14.40 \\
67.85 \pm 22.63 \\
\end{array}$ & $\begin{array}{l}0.787 \\
0.502\end{array}$ & $\begin{array}{l}16.95 \pm 4.76 \\
16.51 \pm 4.76 \\
16.46 \pm 4.75 \\
16.71 \pm 6.44 \\
\end{array}$ & $\begin{array}{l}0.130 \\
0.942\end{array}$ & $\begin{array}{l}84.30 \pm 18.60 \\
83.00 \pm 19.53 \\
86.29 \pm 17.58 \\
84.57 \pm 28.37\end{array}$ & $\begin{array}{l}0.551 \\
0.648\end{array}$ \\
\hline $\begin{array}{l}\text { Cinsiyet } \\
\text { Kiz } \\
\text { Erkek }\end{array}$ & $\begin{array}{c}225(69.9) \\
97(30.1)\end{array}$ & $\begin{array}{l}70.05 \pm 14.44 \\
61.46 \pm 18.29\end{array}$ & $\begin{array}{l}4.508 \\
\mathbf{0 . 0 0 0}\end{array}$ & $\begin{array}{l}16.90 \pm 4.76 \\
15.81 \pm 4.75\end{array}$ & $\begin{array}{l}1.881 \\
0.061\end{array}$ & $\begin{array}{l}86.96 \pm 17.16 \\
77.27 \pm 21.59\end{array}$ & $\begin{array}{l}4.284 \\
\mathbf{0 . 0 0 0}\end{array}$ \\
\hline $\begin{array}{l}\text { Sinıf } \\
1 . \text { sinif } \\
4 . \text { sinif } \\
\end{array}$ & $\begin{array}{c}235(73.0) \\
87(27.0) \\
\end{array}$ & $\begin{array}{l}66.28 \pm 16.85 \\
70.67 \pm 13.71 \\
\end{array}$ & $\begin{array}{l}-2.181 \\
\mathbf{0 . 0 3 0} \\
\end{array}$ & $\begin{array}{l}16.70 \pm 4.77 \\
16.22 \pm 4.80\end{array}$ & $\begin{array}{l}0.787 \\
0.432 \\
\end{array}$ & $\begin{array}{l}82.98 \pm 19.83 \\
86.90 \pm 16.74\end{array}$ & $\begin{array}{r}-1.642 \\
0.102 \\
\end{array}$ \\
\hline $\begin{array}{l}\text { En Uzun } \\
\text { Yaşanılan Yer } \\
\text { Köy } \\
\text { İlçe } \\
\text { Şehir } \\
\text { Büyükşehir }\end{array}$ & $\begin{array}{c}34(10.6) \\
72(22.4) \\
119(37.0) \\
97(30.1)\end{array}$ & $\begin{array}{l}68.94 \pm 11.35 \\
67.86 \pm 15.30 \\
64.76 \pm 18.44 \\
69.97 \pm 14.87\end{array}$ & $\begin{array}{l}2.018 \\
0.111\end{array}$ & $\begin{array}{l}16.91 \pm 4.69 \\
17.34 \pm 4.94 \\
15.56 \pm 4.56 \\
17.12 \pm 4.79\end{array}$ & $\begin{array}{l}2.939 \\
\mathbf{0 . 0 3 3}\end{array}$ & $\begin{array}{l}85.85 \pm 14.27 \\
85.20 \pm 18.74 \\
80.32 \pm 21.15 \\
87.10 \pm 17.63\end{array}$ & $\begin{array}{l}2.558 \\
0.055\end{array}$ \\
\hline $\begin{array}{l}\text { Annenin } \\
\text { Eğitim Düzeyi } \\
\text { Okuryazar değil } \\
\text { Okuryazar } \\
\text { İlköğretim } \\
\text { Lise } \\
\text { Üniversite }\end{array}$ & $\begin{array}{c}29(9.0) \\
22(6.8) \\
215(66.8) \\
48(14.9) \\
8(2.5)\end{array}$ & $\begin{array}{l}67.31 \pm 14.12 \\
64.00 \pm 19.79 \\
67.69 \pm 15.76 \\
68.22 \pm 17.62 \\
67.00 \pm 16.50 \\
\end{array}$ & $\begin{array}{l}0.290 \\
0.884\end{array}$ & $\begin{array}{l}15.34 \pm 2.62 \\
16.77 \pm 4.22 \\
16.64 \pm 1.07 \\
16.56 \pm 2.54 \\
18.75 \pm 5.83 \\
\end{array}$ & $\begin{array}{l}0.913 \\
0.456\end{array}$ & $\begin{array}{l}82.65 \pm 16.66 \\
80.77 \pm 23.36 \\
84.33 \pm 18.67 \\
84.79 \pm 20.80 \\
85.75 \pm 19.02\end{array}$ & $\begin{array}{l}0.244 \\
0.913\end{array}$ \\
\hline $\begin{array}{l}\text { Babanın } \\
\text { Eğitim Düzeyi } \\
\text { Okuryazar değil } \\
\text { Okuryazar } \\
\text { İlköğretim } \\
\text { Lise } \\
\text { Üniversite } \\
\end{array}$ & $\begin{array}{c}5(1.6) \\
17(5.3) \\
154(47.8) \\
106(32.9) \\
40(12.4) \\
\end{array}$ & $\begin{array}{c}74.80 \pm 6.18 \\
62.52 \pm 18.16 \\
68.65 \pm 14.72 \\
66.58 \pm 17.59 \\
66.42 \pm 17.32 \\
\end{array}$ & $\begin{array}{l}0.983 \\
0.417\end{array}$ & $\begin{array}{l}16.80 \pm 3.27 \\
14.64 \pm 4.55 \\
16.83 \pm 4.69 \\
16.15 \pm 4.91 \\
17.47 \pm 4.85 \\
\end{array}$ & $\begin{array}{l}1.380 \\
0.241\end{array}$ & $\begin{array}{c}91.60 \pm 6.80 \\
77.17 \pm 20.59 \\
85.49 \pm 17.54 \\
82.73 \pm 20.59 \\
83.90 \pm 20.83 \\
\end{array}$ & $\begin{array}{l}1.093 \\
0.360\end{array}$ \\
\hline
\end{tabular}


Tablo 2. Öğrencilerin meslek seçimine ve mezun olunca çalışmayı düşündükleri alanlara ilişkin görüşleri ile hemşirelik mesleğini algılama ölçeği puanların karşılaştırılması

\begin{tabular}{|c|c|c|c|c|c|c|c|}
\hline $\begin{array}{l}\text { Meslek Seçimine } \\
\text { İlişkin Görüşler }\end{array}$ & n $(\%)$ & $\begin{array}{c}\text { Mesleki } \\
\text { Nitelikler } \\
\text { X } \pm \text { SD } \\
\end{array}$ & $\begin{array}{c}\text { ANOVA } \\
\mathbf{t} \\
\mathbf{p} \\
\end{array}$ & $\begin{array}{c}\text { Mesleki } \\
\text { Statü } \\
\mathbf{X} \pm \text { SD } \\
\end{array}$ & $\begin{array}{c}\text { ANOVA } \\
\mathbf{t} \\
\mathbf{p} \\
\end{array}$ & $\begin{array}{c}\text { Ölçek Toplam } \\
\text { Puan } \\
\text { X } \pm \text { SD } \\
\end{array}$ & $\begin{array}{c}\text { ANOVA } \\
\mathbf{t} \\
\mathbf{p} \\
\end{array}$ \\
\hline $\begin{array}{l}\text { İsteyerek Seçme } \\
\text { Durumu } \\
\text { Evet } \\
\text { Kismen } \\
\text { Hayır }\end{array}$ & $\begin{array}{l}201(62.4) \\
95(29.5) \\
26(8.1)\end{array}$ & $\begin{array}{l}67.91 \pm 16.36 \\
66.91 \pm 16.13 \\
66.03 \pm 15.09\end{array}$ & $\begin{array}{l}0.233 \\
0.792\end{array}$ & $\begin{array}{l}17.07 \pm 4.85 \\
15.95 \pm 4.25 \\
14.92 \pm 5.52\end{array}$ & $\begin{array}{l}3.518 \\
\mathbf{0 . 0 3 1}\end{array}$ & $\begin{array}{l}84.99 \pm 19.69 \\
82.87 \pm 18.30 \\
80.96 \pm 17.34\end{array}$ & $\begin{array}{l}0.765 \\
0.466\end{array}$ \\
\hline $\begin{array}{l}\text { Üniversite Sınavındaki } \\
\text { Tercih Sirası } \\
\text { 1. tercih } \\
\text { 2.-5. tercih } \\
\text { 6.-9. tercih } \\
\text { 10. tercih ve üzeri }\end{array}$ & $\begin{array}{c}213(66.1) \\
75(23.3) \\
16(5.0) \\
18(5.6)\end{array}$ & $\begin{array}{l}68.29 \pm 15.59 \\
66.25 \pm 17.49 \\
62.50 \pm 15.97 \\
67.22 \pm 17.45\end{array}$ & $\begin{array}{l}0.829 \\
0.478\end{array}$ & $\begin{array}{l}16.95 \pm 4.72 \\
16.00 \pm 4.85 \\
14.81 \pm 4.72 \\
16.00 \pm 4.88\end{array}$ & $\begin{array}{l}1.639 \\
0.180\end{array}$ & $\begin{array}{l}85.24 \pm 18.36 \\
82.25 \pm 20.85 \\
77.31 \pm 18.12 \\
83.22 \pm 20.58\end{array}$ & $\begin{array}{l}1.178 \\
0.318\end{array}$ \\
\hline $\begin{array}{l}\text { Hemşireliğe İlişkin } \\
\text { Duygular } \\
\text { Hemşireliği seviyor } \\
\text { Hemşireliği kısmen } \\
\text { seviyor } \\
\text { Hemşireliği sevmiyor }\end{array}$ & $\begin{array}{c}214(66.5) \\
88(27.3) \\
\\
20(6.2)\end{array}$ & $\begin{array}{l}69.22 \pm 15.81 \\
63.97 \pm 16.85 \\
64.00 \pm 14.27\end{array}$ & $\begin{array}{l}3.851 \\
\mathbf{0 . 0 2 2}\end{array}$ & $\begin{array}{l}17.35 \pm 4.83 \\
15.23 \pm 4.07 \\
14.05 \pm 5.13\end{array}$ & $\begin{array}{l}9.602 \\
\mathbf{0 . 0 0 0}\end{array}$ & $\begin{array}{l}86.58 \pm 19.06 \\
79.21 \pm 18.58 \\
78.05 \pm 17.02\end{array}$ & $\begin{array}{l}5.868 \\
\mathbf{0 . 0 0 3}\end{array}$ \\
\hline $\begin{array}{l}\text { Mezun Olunca } \\
\text { Çalışması } \\
\text { Düşünülen Alan } \\
\text { Hastanede hemşire } \\
\text { Hastanede yönetici } \\
\text { Hemşire okulunda } \\
\text { eğitimci } \\
\text { Sağlıkla ilgili } \\
\text { hemşirelik dışında } \\
\text { başka bir iş } \\
\text { Sağlıkla ilgili } \\
\text { olmayan başka bir iş }\end{array}$ & $\begin{array}{c}113(35.1) \\
118(36.6) \\
80(24.8) \\
6(1.9) \\
5(1.6)\end{array}$ & $\begin{array}{l}67.53 \pm 16.73 \\
67.09 \pm 15.17 \\
68.23 \pm 17.51 \\
66.00 \pm 12.31 \\
64.40 \pm 10.45\end{array}$ & $\begin{array}{l}0.118 \\
0.976\end{array}$ & $\begin{array}{l}17.06 \pm 4.83 \\
16.39 \pm 4.31 \\
16.21 \pm 5.41 \\
16.83 \pm 5.03 \\
15.20 \pm 3.19\end{array}$ & $\begin{array}{l}0.553 \\
0.697\end{array}$ & $\begin{array}{l}84.59 \pm 20.23 \\
83.49 \pm 17.25 \\
84.45 \pm 20.83 \\
82.83 \pm 16.25 \\
79.60 \pm 12.68\end{array}$ & $\begin{array}{l}0.129 \\
0.972\end{array}$ \\
\hline $\begin{array}{l}\text { Mesleğe Hazır } \\
\text { Hissetme Durumu } \\
\text { Evet } \\
\text { Kismen } \\
\text { Hayır }\end{array}$ & $\begin{array}{c}173(53.7) \\
121(37.6) \\
28(8.7)\end{array}$ & $\begin{array}{l}68.04 \pm 16.50 \\
66.52 \pm 15.91 \\
68.00 \pm 15.43\end{array}$ & $\begin{array}{l}0.327 \\
0.722\end{array}$ & $\begin{array}{l}17.16 \pm 5.02 \\
15.87 \pm 4.44 \\
15.96 \pm 4.24\end{array}$ & $\begin{array}{l}2.859 \\
0.059\end{array}$ & $\begin{array}{l}85.20 \pm 19.96 \\
82.40 \pm 18.15 \\
83.96 \pm 17.68\end{array}$ & $\begin{array}{l}0.763 \\
0.467\end{array}$ \\
\hline $\begin{array}{l}\text { Okula Gelmeden } \\
\text { Önce Meslek } \\
\text { Hakkındaki } \\
\text { Düşünce } \\
\text { Olumlu } \\
\text { Kısmen olumlu } \\
\text { Kararsız } \\
\text { Kısmen olumsuz } \\
\text { Olumsuz }\end{array}$ & $\begin{array}{c}138(42.9) \\
95(29.5) \\
45(14.0) \\
27(8.4) \\
17(5.3)\end{array}$ & $\begin{array}{l}67.93 \pm 16.71 \\
67.28 \pm 15.34 \\
68.71 \pm 16.44 \\
65.11 \pm 17.96 \\
65.17 \pm 13.20\end{array}$ & $\begin{array}{l}0.325 \\
0.861\end{array}$ & $\begin{array}{l}17.90 \pm 4.73 \\
15.53 \pm 4.58 \\
15.77 \pm 4.13 \\
16.77 \pm 4.50 \\
13.35 \pm 5.31\end{array}$ & $\begin{array}{l}6.462 \\
\mathbf{0 . 0 0 0}\end{array}$ & $\begin{array}{l}85.84 \pm 20.17 \\
82.82 \pm 18.23 \\
84.48 \pm 18.08 \\
81.88 \pm 20.23 \\
78.52 \pm 15.51\end{array}$ & $\begin{array}{l}0.847 \\
0.496\end{array}$ \\
\hline $\begin{array}{l}\text { Bölüme Girdikten } \\
\text { Sonra Meslek } \\
\text { Hakkındaki } \\
\text { Düşünce } \\
\text { Olumlu } \\
\text { Kısmen olumlu } \\
\text { Kararsız } \\
\text { Kısmen olumsuz } \\
\text { Olumsuz }\end{array}$ & $\begin{array}{c}184(57.1) \\
99(30.7) \\
22(6.8) \\
9(2.8) \\
8(2.5)\end{array}$ & $\begin{array}{c}68.28 \pm 16.62 \\
67.86 \pm 15.42 \\
60.13 \pm 15.95 \\
65.11 \pm 17.91 \\
66.50 \pm 9.73\end{array}$ & $\begin{array}{l}1.326 \\
0.260\end{array}$ & $\begin{array}{l}17.31 \pm 4.83 \\
16.39 \pm 4.62 \\
13.59 \pm 3.83 \\
13.33 \pm 2.39 \\
13.62 \pm 4.50\end{array}$ & $\begin{array}{l}5.354 \\
\mathbf{0 . 0 0 0}\end{array}$ & $\begin{array}{l}85.60 \pm 19.80 \\
84.26 \pm 18.27 \\
73.72 \pm 16.62 \\
78.44 \pm 18.63 \\
80.12 \pm 10.62\end{array}$ & $\begin{array}{l}2.225 \\
0.066\end{array}$ \\
\hline
\end{tabular}

Mesleki nitelikler alt boyutu ile cinsiyet $(p<0.001)$, sinıf $(p<0.05)$ ve öğrencilerin hemşireliğe ilişkin duyguları $(\mathrm{p}<0.05)$ arasında istatistiksel düzeyde de anlamlılık saptanmıştır. Mesleki statü alt boyutu ile öğrencilerin uzun süredir yaşadıkları yer $(\mathrm{p}<0.05)$, hemşireliği isteyerek seçme $(\mathrm{p}<0.05)$, hemşireliğe ilişkin duyguları $(\mathrm{p}<0.001)$, okula gelmeden önce hemşireliğe ilişkin düşünceleri 
$(\mathrm{p}<0.001)$ ve bölüme başladıktan sonra hemşireliğe ilişkin düşünceleri $(\mathrm{p}<0.001)$ arasında anlamlılık saptanmıştır. HMAÖ toplam ölçek puan ortalamaları ile cinsiyet $(\mathrm{p}<0.001)$ ve hemşirelik hakkındaki duyguları $(\mathrm{p}<0.01)$ arasında istatistiksel olarak anlamlılık bulunmuştur (Tablo 1 ve 2$)$. LSD post hoc testi sonucunda hemşireliği seven, dördüncü sınıf kız öğrencilerin hemşirelik mesleği algılarının hemşireliği sevmeyenlere, birinci sınıf erkek öğrencilere göre daha yüksek olduğu saptanmıştır.

Tablo 3. Öğrencilerin hemşirelik mesleğini algılama ölçeği puanları

\begin{tabular}{|l|c|}
\hline Hemşirelik Mesleğini Algılama Ölçeği Toplam Puanı ve Ölçek Alt Boyutlarının Puanı & X \pm SD \\
\hline Mesleki nitelikler & $67.46 \pm 16.16$ \\
Mesleki statü & $16.57 \pm 4.78$ \\
Ölçek toplam puanı & $84.04 \pm 19.10$ \\
\hline
\end{tabular}

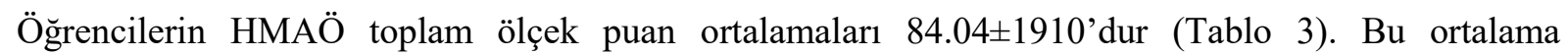
öğrencilerin mesleki algı düzeylerinin oldukça iyi olduğunu göstermektedir.

\section{TARTIŞMA}

Mesleklerin pek çoğunda kişinin başarılı olabilmesi ve profesyonelleşmesi, mesleği bilerek ve isteyerek seçmekle yakından ilişkilidir (Sabancığulları ve Doğan, 2012; Özsoy 2000).Bu araştırmada öğrencilerin mesleği isteyerek seçme düzeyleri (\%62.4), Yücel vd. (2011) (\%50,.7), Kızgut ve Ergöl (2011) (\%45.2), Dinç, Kaya ve Şimşek, (2007) (\%42.7) ve Eşer, Khorshid ve Denat (2008) (\%35.1) çalışmalarındaki konu ile ilgili bulgulara göre daha yüksek bulunmuştur. Bu durum yıllar ilerledikçe öğrencilerin hemşirelik mesleğine isteyerek ve bilinçli olarak geldiklerini düşündürmektedir. Dolayısıyla bu durum hemşirelik öğrencilerinin mezun olduktan sonra hemşirelik mesleğini severek yapacaklarını, mesleği ve meslektaşlarını seveceklerini, mesleki ilişkileri ve iş doyumlarının yüksek olabileceğini ve tüm bunlar nedeniyle de mesleği algılamaları ve bunun topluma olumlu yansımalarını düşündürmesi bakımından son derece önemlidir.

Mesleklerin pek çoğunda kişinin başarılı olabilmesi fiziksel özellikleri, mesleği bilerek ve isteyerek seçmiş olmaları ile yakından ilgilidir (Beydağ, Gündüz ve Özer, 2008). Bu çalışmada öğrencilerin üniversite sınavında hemşireliği birinci sırada $(\% 66.1)$ ve ilk beşinci sırada $(\% 89.4)$ tercih etme düzeyleri oldukça yüksek bulunmuştur. Benzer bir çalışmada öğrencilerin \%26'sının ise hemşirelik mesleğini birinci sırada, \%48'inin hemşireliği ilk 5 tercih sırada tercih ettiği saptanmıştır (Eşer, Khorshid ve Denat, 2008). Yücel vd. (2011) çalışmasında \%23'ünün birinci sırada, \%55.1'inin hemşireliği ilk 5 sırada tercih ettiği belirlenmiştir. Sözü edilen çalışmalardaki tercih edilme düzeyleri bu çalışmanın sonuçlarına göre düşük olsa da son yıllarda yapılan çalışmalarda öğrencilerin hemşireliği ilk beş tercih sıralamasına aldıkları saptanmıştır (Akbaş, Alparslan ve Öztunç, 2003; Öztürk ve Bahçecik, 2003; Demirkıran, Türk ve Denat, 2005; Bezci ve Bayık, 2005; Sarıtaş, Derin ve Sarıtaş, 2014). Hemşirelik mesleğinin ilk sıralarda tercih edilmesi mesleğin istendiğini göstermesi açısından önemli bir durumdur. Bu çalışmada olduğu gibi Yücel vd. (2011) çalışmasında da öğrencilerin çoğunun hemşirelik mesleğini sevdiği saptanmıştır. Çalışmamızda olduğu gibi yapılan bazı çalışmalarda öğrencilerin ilk sıralarda yönetici hemşire olmak istedikleri saptanmıştır (Öztürk ve Bahçecik, 2003; Eşer, Khorshid ve Denat, 2008; Yücel vd., 2011). Yücel vd. (2011) yaptıkları çalışma sonucunda ki gibi bu çalışmada da öğrenciler kendilerini mesleğe hazır hissetmektedir. Bu sevindirici durum, hemşirelik eğitiminin oldukça etkili olduğunu düşündürmektedir.

$\mathrm{Bu}$ çalışmada öğrenciler, olumlu düşünceler ile okula gelmişlerdir. Bölüme başladıktan sonra bu düşüncelerinin gittikçe daha olumluya dönüştüğü saptanmıştır. Bu sonuç, öğrenciler tarafindan hemşirelik mesleğinin okula başlamadan önce belli ölçülerde tanındığını düşündürmektedir. Turgay vd. (2005) çalışmasında da bu araştırmadakine benzer şekilde okula gelmeden önce ile sonrasındaki düşünceler olumlu yönde artmaktadır. Öğrencilerin öğretmen ve klinik eğiticilerden önemli derecede etkilendiklerini ve bu etkilenimin öğrencilerin profesyonel hemşireler olarak kendilerini algılamalarını etkileyebileceğini belirtilmektedir (Gray ve Smith, 1999). Hemşirelerin meslek algısının olumlu gelişmesinde eğitim sürecinde öğrenci hemşirelerin kendi kişisel ve mesleki değerlerini birbiri ile bütünleştirebilmeleri önemlidir. Toplumun hemşireliğe bakış açısından etkilenmiş olan öğrencilerin eğitimleri sırasında hemşireliğe ilişkin başlangıçtaki algıları, gerçek hemşirelik anlayışı ile yer değiştirmeye başlar. $\mathrm{Bu}$ süreçte öğrenci, hemşireliğe ilişkin bilgi, beceri, tutum, değer ve etik standartları içselleştirir ve onları davranışlara dönüştürür (Sabancığulları ve Doğan, 2012). 
Öğrenciler özellikle klinik uygulamalarda meslekleriyle daha yakından tanışmaktadır. Mesleklerinin sağl1k ekibi içindeki yerini kavramaya başlamakta ve bunun sonucunda hemşirelik mesleğine yönelik algılamaları olumlu yönde değişebilmektedir.

Olumlu meslek algısı ve mesleki niteliklerle donanmış bir hemşirenin topluma sunduğu hizmet daha kaliteli olacaktır. Ayrıca mesleğin toplumdaki yeri ve statüsü bundan olumlu yönde etkilenecektir. Çünkü bir mesleğin değeri topluma sunduğu hizmetin etkinliği ile ölçülür (Tan vd., 2007; Cerit ve Çoşkun, 2018). Mesleğe uyum sağlamada ve verimli bir çalışma yaşamı sürdürmede o mesleğe ilişkin olumlu bir alg1 ve tutuma sahip olmak önemlidir (Demirkıran vd., 2005).Yapılan çalışmalarda bu çalışmanın sonucunu destekler nitelikte hemşirelik öğrencilerinin meslek algılarının oldukça olumlu olduğu bulunmuştur (Grainger ve Bolan, 2006; Dinç, Kaya ve Şimşek, 2007; Eşer, Khorshid ve Denat, 2008; Zhang ve Petrini, 2008; Tüfekçi ve Y1ldı, 2009; Yücel vd., 2011; Hendel ve Kagan, 2011; Patidar vd., 2011; Al Jarrah, 2013; Denat, Gürol ve Şahbaz, M. 2016; Y1lmaz vd., 2016; Cerit ve Çoşkun, 2018). Öğrencilerin hemşirelik mesleğine ilişkin olumlu algıları, eğitim öğretim sürecinde mesleğe ilişkin uzmanlık bilgi ve becerisini kazanma, mesleki değerleri benimseme ve bunları mesleki uygulamalarına yansıtabilme konusunda hazır olduklarını göstermesi bakımından belirleyici olduğu söylenebilir.

Hemşirelik öğrencileri, hemşireliğin doğasına yerleşmiş inançları ile hemşirelik eğitimine başlarlar. Daha sonra çok sayıda faktör hemşirelik öğrencilerinin mesleki kimlik sürecine katılır. Mesleki algının eğitim sürecinde olumlu yönde gelişmesi beklenir (Safadi vd., 2011). Bu çalışmada kız, dördüncü sınıf ve hemşireliği seven öğrencilerin mesleki nitelikler konusundaki olumlu düşünceleri erkek, birinci sınıf ve hemşireliği sevmeyen öğrencilere göre daha yüksek bulunmuştur. Bu sonuç, beklenen bir sonuçtur. Çünkü yapılan çalışmalar kız öğrencilerin erkeklere göre hemşireliğe daha çok isteyerek geldiklerini göstermektedir (Natan ve Becker, 2010; Özveren, Gülnar ve Özden, 2017). Y1lmaz ve Karadağ'ın (2011) çalışmasında erkek öğrencilerin, hemşirelik mesleğini seçerken bilinçli tercih yapmadıkları saptanmıştır. Birinci sınıfa olumlu düşüncelerle gelen öğrencilerin eğitimlerinin sonuna geldiklerinden düşüncelerinin daha da olumluya dönüştüğüne ilişkin bu çalışmanın bulgusu sözü edilen bulguyu destekler niteliktedir. Denat vd. nin (2016) 137 hemşirelik öğrencisi ile gerçekleştirdikleri çalışmada, çalışmamızda olduğu gibi öğrencilerin birinci sınıfta sahip oldukları olumlu meslek algısının eğitim sürecinden etkilenerek dördüncü sınıfta pozitif yönde arttığı saptanmış olup eğitim sürecinde öğrencilerin meslek algısını artırmaya yönelik güdülenmesinin önemine vurgu yapılmıştır. Yapılan çalışmalar ilk klinik uygulamanın öğrencilerin hemşirelik algısını olumlu yönde etkilediğini göstermektedir. Hemşirelik eğitimi sırasında daha ilk klinik uygulamalardan itibaren öğrencilerin hemşirelik mesleğini algılamaları olumlu yönde değiş̧im göstermektedir (Bezci ve Bayık, 2005; Wang, Shang ve Jin, 2005; Eşer, Khorshid ve Denat, 2008; Bolan ve Grainger, 2009; Safadi vd., 2011; Kızgut ve Ergöl, 2011; Papathanasiou, Tsaras ve Sarafis, 2014). Hemşirelik eğitimi öğrencilerin mesleki algılarını artırmaktadır (Nilsson ve Silén, 2010). Ülkemizde hemşirelik öğrencileriyle yapılan çalışmalarda öğrencilerin meslek algılarının orta düzeyde olduğu, sınıf ilerledikçe hemşirelik hakkındaki düşüncelerinin olumlu olarak değiştiği belirlenmiştir (Özsoy, 2000; Bezci ve Bay1k, 2005; Turgay vd., 2005; Eşer, Khorshid ve Denat, 2008; Yücel vd., 2011). Sonuçlar çalışmamızın sözü edilen bulgusu ile benzerlik göstermektedir. Mesleki nitelikler, meslek üyesinin sahip olduğu kuramsal bilgiyi, psikomotor, problem çözme ve iletişim becerilerini ve mesleki değerlerini yansıtır. Mesleki nitelikler hemşirenin özgüvenini, mesleki saygınlığını ve doyumunu arttırması, insan onuruna yakışır, profesyonel ve duyarlı sağlık bakım hizmeti sunulabilmesi için gereklidir (Cerit ve Çoşkun, 2018). Hemşireliği seven öğrencilerin sevmeyenlere göre mesleki nitelikleri kapsayan değer ve becerilere daha kolay sahip olacaklarından dolayı mesleki algılarının daha olumlu olması kaçınılmaz bir sonuçtur.

\section{SONUÇ}

Sonuç olarak, hemşirelik öğrencilerinin hemşirelik algıları yüksek düzeyde bulunmuştur. Hemşirelik algısı ile bazı sosyo-demografik özellikler ve öğrencilerin hemşirelik hakkındaki düşünceleri arasında anlamlılık saptanmıştır. Hemşirelik öğrencilerinin olumlu meslek algılarının gelişmelerinde, akademisyen ve klinisyen hemşirelerin ve hemşirelik yöneticilerinin önemli bir yeri vardır. Öğrencilik yıllarından itibaren hemşirelik imajının olumlu yönde geliştirilmesi çalışan tüm hemşirelerinin 
sorumluluğundadır. Hemşirelik müfredatlarında meslek algısına ilişkin ders ve konuların eklenmesi gerekmektedir. Klinik uygulamalarda öğrencilerle olumlu iletişimler kurularak öğrenciler desteklenmeli ve iyi rol modelleri olunmalıdır. Ayrıca bu konuda klinisyen ve yönetici hemşirelerle paylaşımlarda bulunulmalıdır. Tüm öğrencilerin ama özellikle de erkek öğrencilerin öğretim elemanlarının danışmanlığı eşliğinde uluslararası ve ulusal hemşirelik kongrelerine katılımı meslek algılarını arttırabilir.

\section{Bilgilendirme/Acknowledgement}

- Bu araştırma, Nancy/Fransa'da yapılan "Nursing Education and Nursing Care Which Future" isimli kongrede sözel bildiri olarak sunulmuştur.

- Yazarlar arasında çıkar çatışması bulunmamaktadır.

- Ölçeği kullanmadan önce Türkçe'ye geliştirilen yazarlardan izin, hemşirelik öğrencilerinden bilgilendirilmiş onam ve kurum yöneticilerinden yazılı ve sözlü izinler alınmıştır.

- $\quad \mathrm{Bu}$ araştırma, 22.09.2014-26.09.2014 tarihleri arasında Ahi Evran Üniversitesi Bilimsel Araştırmalar Projesi tarafindan PYO-SA.4010.14.002 numaralı proje olarak kabul edilmiş olup yurt dişında sözel bildiri olarak sunulması konusunda desteklenmiştir.

- Yazar Katkıları: ŞDG: Fikir; ŞDG, AÜ: Tasarım; AÜ, ŞDG: Kaynakların toplanması; AÜ: Analiz ve/veya yorum; AÜ, ŞDG: Literatür taraması; AÜ, ŞDG: Yazıyı yazan; ŞDG, AÜ: Eleştirel inceleme

\section{KAYNAKÇA}

Akbaş, M. Alparslan, N. ve Öztunç, G. (2003). Çukurova Üniversitesi Adana Sağlık Yüksekokulu I. Sınıf öğrencilerinin mesleği tercih etme, okula başlama ve devam etmelerine ilişkin görüşlerini incelenmesi. I. Uluslararası ve V. Ulusal Hemşirelik Eğitimi Kongresi Kitabı, 187-190. İstanbul: Özlem Grafik Matbaacılık.

Al Jarrah, I.A.T. (2013). Associate nursing students' perceptions toward nursing profession in Jordan. European Scientific Journal, 9(6), 147-166.

Bezci, G. ve Bayık, A. (2005). Hemşirelik öğrencilerinin hemşireliği algılamaları. IV. Ulusal Hemşirelik Öğrencileri Kongresi Kitabı, 51. Ankara, Kök Yayıncılık.

Beydağ, K. Gündüz, A. ve Özer, F. (2008). Sağlik yüksekokulu öğrencilerinin eğitimlerine ve mesleklerine bakış açıları, meslekten beklentileri. Pamukkale Tip Dergisi, 1(3), 137-142.

Bolan, C. ve Grainger, P. (2009). Students in the BN program-do their perceptions change? Nurse Educ Today, 29(7), 775-779.

Cerit, B. ve Çoşkun, S. (2018). Hemşirelik bölümü öğrencilerinin mesleki güdülenme düzeyinin meslek algısına etkisi. Dokuz Eylül Üniv. Hemşirelik Fak. E-Dergisi, 11(4), 283-289.

Demirkıran, F. Türk, G. ve Denat, Y. (2005). İlk klinik uygulama öğrencilerin mesleklerine ilişkin görüşlerini etkiler mi? Ege Üniversitesi Hemşirelik Yüksekokulu Dergisi Özel Sayl.

Denat, Y. Gürol, G. A. ve Şahbaz, M. (2016). Change in students' perception of profession during nursing education in Turkey: a longitudinal study. International Journal of Human Sciences, 13(1), 900-908.

Dinç, S. Kaya, Ö. ve Şimşek, Z. (2007). Harran Üniversitesi Sağlık Yüksekokulu Öğrencilerinin hemşirelik mesleği hakkındaki bilgi, düşünce ve beklentileri. Atatürk Üniversitesi Hemşirelik Yüksekokulu Dergisi, 10(1), 1-19.

Eşer, İ. Khorshid, L. ve Denat, Y. (2006). Hemşirelik mesleğini algılama ölçeği geçerlik güvenirlik çalışması. Çınar Dergisi, 10(1), 31-39.

Eşer, İ. Khorshid, L. ve Denat, Y. (2008). Hemşirelik mesleğini algılamada ilk klinik uygulamanın etkisi. Ege Üniversitesi Hemşirelik Yüksek Okulu Dergisi, 24(1), 15-26.

Grainger, P. ve Bolan, C. (2006). Perceptions of nursing as a career choice of students in the Baccalaureate nursing program. Nurse Educ. Today, 26(1), 38-44. 
Gray, M. ve Smith, L. N. (1999). The professional socialization of diploma of higher education in nursing students (Project 2000): A longitudinal qualitative study. Journal of Advanced Nursing, 29(3), 639-647.

Hendel, T. ve Kagan, I. (2011). Professional image and intention to emigrate among Israeli nurses and nursing students. Nurse Educ Today, 31(3), 259-262.

Karaöz, S. (2002). Hemşirelik öğrencilerinin eğitimleri sırasında mesleğe ilişkin algılarındaki değişimin incelenmesi: hemşireliğe giriş dersinin bu değişimdeki rolü. Cumhuriyet Üniversitesi Hemşirelik Yüksek Okulu Dergisi, 6(2), 10-20.

Kızgut, S. ve Ergöl, Ş. (2011). Sağlık yüksekokulu öğrencilerinin hemşireliği algılayışı hemşirelik rollerine ve hemşireliğin geleceğine bakışı. Anadolu Hemşirelik ve Sağlık Bilimleri Dergisi, 14(2), 10-16.

Kotler, P. (2001). A Framework for Marketing Management. Upper Saddle River, NJ: Prentice Hall.

Natan, M. B. ve Becker, F. (2010). Israelis'percieved motivation for choosing a nursing career. Nurse Educ Today, 30, 308-313.

Nilsson, A.F. ve Silén, C. (2010). You have to know why: The influence of different curricula on nursing students' perceptions of nursing. Scandinavian Journal of Education Research, 54, $631-42$.

Öztürk, H. ve Bahçecik, N. Öğrencilerin meslek olarak hemşireliği seçmelerini etkileyen faktör ve gelecekteki mesleki beklentileri. I. Uluslararası ve V. Ulusal Hemşirelik Eğitimi Kongresi Kitabl, 387-392. İstanbul: Özlem Grafik Matbaacılık.

Özsoy, S. A. (2000). Toplumda hemşirelik imajının belirlenmesi. Ege Üniversitesi Hemşirelik Yüksekokulu Dergisi, 16(2-3),1-19.

Özveren, H. Gülnar, E. ve Özden, D. (2017). Hemşirelik öğrencilerinin meslek seçimini etkileyen faktörlerin belirlenmesi. Turkish Journal of Clinics and Laboratory, 8(2), 52-64.

Papathanasiou, I. V. Tsaras, K. ve Sarafis, P. (2014). Views and perceptions of nursing students on their clinical learning environment: teaching and learning. Nurse Educ Today, 34(1), 57-60.

Patidar, A. B., Kaur, J., Sharma, S. K., ve Sharma, N. (2011). Future nurses' perception towards profession and carrier plans: A cross sectional survey in state Punjab. Nursing and Midwifery Research Journal, 7(4).

Safadi, R. R. Saleh, M. Y. N. Nassar, O. S. Amre, H. M. ve Froelicher, E. S.(2011). Nursing students' perceptions of nursing: a descriptive study of four cohorts. Int Nurs Rev, 58(4), 420-427.

Sabancioğulları, S. ve Doğan, S. (2012). Profesyonel kimlik gelişimi ve hemşirelik. Anadolu Hemşirelik ve Sağlık Bilimleri Dergisi, 15(4), 275-282.

Sarıtaş, S. Ç. Derin, N. ve Sarıtaş, S. (2014). Hemşirelik öğrencilerinde mesleki imaj algısının meslekte kalma niyeti üzerine etkisi. İnönü Üniversitesi Sağlık Bilimleri Dergisi, 3(1), 29-32.

Şimşek, A. K. ve Alpar, Ş. E. (2019). Toplumun hemşirelik mesleğine yönelik imaj algısı: Sistematik derleme. Sakarya Üniversitesi Holistik Sağlık Dergisi, 2(1), 32-46.

Tan, M. Yüncü, S. Şentürk, Ö. ve Yıldız, Ö. (2007). Üniversite öğrencilerinin hemşireliğe bakış açılar1. Atatürk Üniversitesi Hemşirelik Yüksekokulu Dergisi, 10(1), 22-29.

Turgay, A. S. Karaca, B. Ceber, E. ve Aydemir G. (2005). Hemşirelik öğrencilerinin mesleği algılayışları. Atatürk Üniversitesi Hemşirelik Yüksekokulu Dergisi, 8(1), 54-62.

Tüfekçi, F.G. ve Yıldız, A. (2009). Öğrencilerin hemşireliği tercih etme gerekçeleri gelecekleri ile ilgili görüşleri. Anadolu Hemşirelik ve Sağllk Bilimleri Dergisi, 12(1), 31-37.

Wang, B. Q. Shang, L. P. ve Jin, R. H. (2005). Fostering of professional sensibility of nursing probationers. Chinese Nursing Research, 19, 80-81. 
Yılmaz, A. A. İlçe, A. Çiçek, S. C. Yüzden G. E. ve Yiğit Ü. (2016). The effect of a career activity on the students' perception of the nursing profession and their career plan: A single-group experimental study. Nurse Educ Today, 39, 176-180.

Yılmaz, M. ve Karadağ, G. (2011). Erkek öğrenci hemşireler hemşirelik mesleğini nasıl algıllıyor? Maltepe Üniversitesi Hemşirelik Bilim ve Sanatı Dergisi, 4(1), 21-28.

Yücel, Ş. Ç. Güler, E. K. Eşer, İ. ve Khorshid, L. (2011). İki farklı eğitim sistemi ile öğrenim göre hemşirelik son sınıf öğrencilerinin hemşirelik mesleğini algılama durumlarının karşılaştırılması. Ege Üniversitesi Hemşirelik Yüksekokulu Dergisi, 27(3), 1-8.

Zhang, M. F. ve Petrini, M. A. (2008). Factors influencing Chinese undergraduate nursing students' perceptions of the nursing profession. International Nursing Review, 55(3), 274-280. 